\title{
Figures
}

1.1 Active Earners in Hungary, by Industrial Branch

1.2 Distribution of Active Earners in Hungary Between the Ages of 15 and 54 , by Gender

1.3 Percentage of Working-Class Children Among First-Year Students at the Karl Marx University of Economics, 1949-84 13

2.I The Hungarian Educational System

2.2 Mean Number of Years of Schooling Completed by Hungarians, by Gender and Birth Cohort

2.3 Percentage of Hungarians Completing Primary School, by Gender and Birth Cohort

2.4 Percentage of Hungarian Primary School Graduates Attending Secondary School, by Gender and Birth Cohort

2.5 Percentage of Hungarian Secondary School Students Completing Secondary School, by Gender and Birth Cohort

2.6 Percentage of Hungarian Secondary School Graduates Attending Tertiary School, by Gender and Birth Cohort

2.7 Percentage of Hungarian Tertiary School Students Completing Tertiary School, by Gender and Birth Cohort

3.I Distribution of Class Positions in First Job 51

3.2 Distribution of Class Positions at Age 30

3.3 Distribution of Class Positions in First Job, Men Only 55

3.4 Distribution of Class Positions in First Job, Women Only 56

3.5 Distribution of Class Positions at Age 30, Men Only 56

3.6 Distribution of Class Positions at Age 30, Women Only 57

4.I Inflow Rates into Hungarian Managerial Class for Men, by Birth Cohort (Intergenerational Tables) 63

4.2 Inflow Rates into Hungarian Managerial Class for Women, by Birth Cohort (Intergenerational Tables)

4.3 Outflow Rates from Hungarian Small Proprietor Class for Men, by Birth Cohort (Intergenerational Tables) 
4.4 Outflow Rates from Hungarian Small Proprietor Class for Women, by Birth Cohort (Intergenerational Tables)

4.5 Changes in Hungarian Class Structure: Scale Values from Unconstrained Model II* for Men (Intergenerational Tables) $\quad 72$

4.6 Changes in Hungarian Class Structure: Scale Values from Unconstrained Model II* for Women (Intergenerational Tables)

4.7 Changes in Hungarian Class Inheritance: Parameter Estimates from Unconstrained Model II* for Men (Intergenerational Tables)

4.8 Changes in Hungarian Class Inheritance: Parameter Estimates from Unconstrained Model II* for Women (Intergenerational Tables)

5.I Inflow Rates into Hungarian Managerial Class for Men, by Birth Cohort (Intragenerational Tables)

5.2 Inflow Rates into Hungarian Managerial Class for Women, by Birth Cohort (Intragenerational Tables)

5.3 Outflow Rates from Hungarian Small Proprietor Class for Men, by Birth Cohort (Intragenerational Tables)

5.4 Outflow Rates from Hungarian Small Proprietor Class for Women, by Birth Cohort (Intragenerational Tables)

5.5 Inflow Rates into Hungarian Houseworker Class for Women, by Birth Cohort (Intragenerational Tables)

5.6 Changes in Hungarian Class Structure: Scale Values from Unconstrained Model II* for Men (Intragenerational Tables)

5.7 Changes in Hungarian Class Structure: Scale Values from Unconstrained Model II* for Women (Houseworkers Excluded) (Intragenerational Tables)

5.8 Changes in Hungarian Class Structure: Scale Values from Unconstrained Model II* for Women (Houseworkers Included) (Intragenerational Tables)

5.9 Changes in Hungarian Class Inheritance: Parameter Estimates from Unconstrained Model II* for Men (Intragenerational Tables)

5.10 Changes in Hungarian Class Inheritance: Parameter Estimates from Unconstrained Model II* for Women (Intragenerational Tables)

7.1 Types of Egalitarian Reform in Socialist Hungary 



\section{Equality by Design}

The Grand Experiment in Destratification in Socialist Hungary 
